\title{
I Rode through the Desert: Equestrian Adaptations of Indigenous Peoples in Southern Hemisphere Arid Zones
}

\author{
Peter Mitchell $^{1,2,3}$ (D)
}

Published online: 15 October 2016

(C) The Author(s) 2016. This article is published with open access at Springerlink.com

\begin{abstract}
One of the most profound consequences of the "Columbian exchange" set in motion by Europe's fifteenth- to nineteenth-century expansion overseas was the introduction of the horse to parts of the world where it had previously been absent. Alongside the internationally well-known Plains of North America, these regions included several southern hemisphere drylands: Patagonia; the Karoo and Kalahari of southern Africa; and the deserts of Australia. This paper explores the equestrian adaptations developed by the Indigenous inhabitants of these three areas and tries to explain the variability apparent in the speed and consequences of their adoption of the horse.
\end{abstract}

Keywords Horse $\cdot$ Columbian exchange $\cdot$ Arid and semi-arid environments $\cdot$ Southern hemisphere $\cdot$ Indigenous peoples

\section{Introduction}

Horses (Equus caballus) are a relatively recent introduction (or, in South America, reintroduction) to the southern hemisphere. Their arrival in the Southern Cone of South America, southern Africa, and Australia formed a key part of the Columbian exchange of human, animal, plant, and microbe populations set in motion by Europe's fifteenthto nineteenth-century expansion overseas (Crosby 1986, 2003). That arrival did not only contribute to a series of longer-term ecological modifications of southern

Peter Mitchell

peter.mitchell@st-hughs.ox.ac.uk

1 School of Archaeology, University of Oxford, Oxford, UK

2 GAES, University of the Witwatersrand, Johannesburg, South Africa

3 St Hugh's College, Oxford OX2 6LE, UK 
hemisphere ecologies that continues today: it also facilitated the eventual colonization and conquest of all three southern continents by populations of European origin, andthe subject of this paper-profoundly impacted their Indigenous inhabitants. For the arid and semi-arid regions of the southern hemisphere (mean annual rainfalls of $<250$ and 250-500 $\mathrm{mm}$ respectively) the recency - and near-simultaneity - of the horse's arrival makes its relationships with the peoples already living there a rewarding topic for comparative study. Strangely, however, but at least partly because of the language limitations of many Anglophone scholars, few, if any, such comparisons have been attempted previously. In this paper I therefore first review the historical trajectories linking people and horses in Patagonia, the Kalahari and Karoo regions of southern Africa, and arid zone Australia (Fig. 1). I then explore some themes of common interest that unite these three southern hemisphere dryland regions: the conditions that may have been necessary for equestrian societies to develop; the ways in which people imagined and visually represented the horse; and the effects that having horses had on how people acquired food for themselves. I also ask how evidence from the world's southern deserts can help us understand the broader circumstances in which novel equestrian adaptations arose in the Americas, Africa, and Australasia after horses went global post-1492.

\section{Southern Hemisphere Horse Histories}

\section{South America's Southern Cone}

Patagonia extends over more than $1,000,000 \mathrm{~km}^{2}$ of South America's Southern Cone, from the Río Colorado in the north to the Strait of Magellan in the south. Given the much higher rainfall of the areas lying west of the Andes in what is now Chile, my discussion focuses on the much larger, Argentine part of Patagonia between the continental divide and the Atlantic Ocean. Argentine Patagonia is mostly a region of arid, steppe-like plains, with trees confined to the foothills of the Andes, sheltered basins, and areas around the Strait of Magellan. Punctuating the steppe-lands, a series of major rivers runs broadly west-to-east to empty into the Atlantic and offer possible corridors for human movement (Borrero et al. 2009): the Colorado, Negro, Chubut, Deseado, Santa Cruz, Gallegos, and others. Patagonia's climate is markedly seasonal in character. Although the piedmont zone

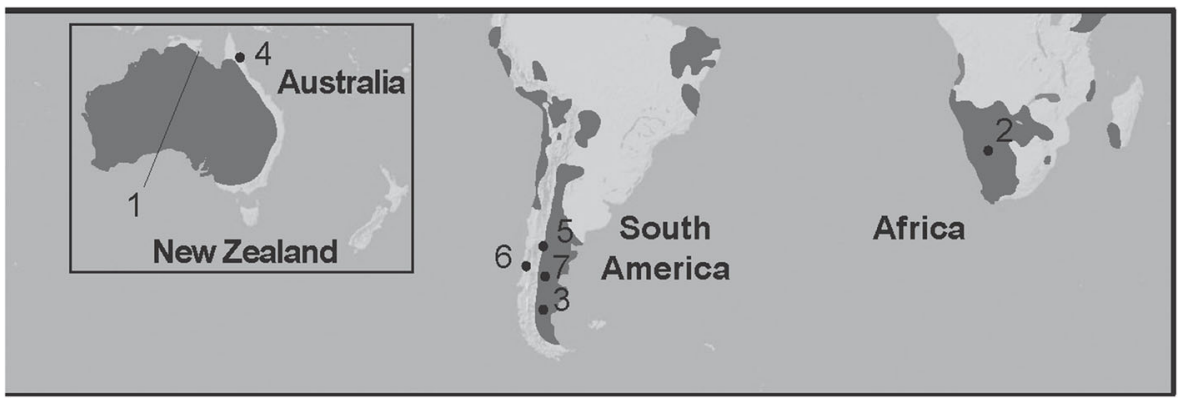

Fig. 1 Map of the world showing the drylands of the southern hemisphere and specific archaeological sites or localities named in the text. These are numbered as follows: 1 Bickerton Island; 2 //Khauxa!nas; 3 Laguna Condor, Lake Strobel; 4 Laura; 5 Paredón Lanfré; 6 Río Cisnes; 7 Río Senguer 
parallel to the Andes receives sufficient rainfall to support forest and woodland, immediately to its east precipitation drops to no more than $150-300 \mathrm{~mm}$ p.a., winds intensify, and temperatures become more extreme; Maquinchao, for example, at an elevation of $888 \mathrm{~m}$ a.s.l. and in the middle of northern Patagonia $\left(41^{\circ} \mathrm{S}\right)$ has recorded maxima and minima of $38{ }^{\circ} \mathrm{C}$ and $-26^{\circ} \mathrm{C}$ respectively. The coast has a more moderate temperature regime, but still shows a significant increase in cold on moving south. It is almost entirely lacking in water and firewood because of the offshore presence of the cold Malvinas (Falkland) Current (Orquera 1987), though the upwelling associated with this does sustain rich fisheries and associated bird and sea-mammal populations. At European arrival, virtually all of Patagonia's inhabitants depended solely upon hunting and gathering for their subsistence, with shellfish, birds, fish, and pinnipeds along the shoreline complementing a focus on guanaco (Lama guanicoe), rhea (Rhea americana; $R$. pennata), and other game inland; plants were of relatively little importance (Barceló et al., 2009; Prates 2009; but see Gómez Otero 2007a), though with some limited access to maize (Zea mays; imported from Chile?) in Neuquén in the Andean foothills of northwestern Patagonia (Lema et al. 2012).

Horses (and their close relatives, the now extinct taxon Hippidion; Der Sarkissian et al. 2015) were part of Patagonia's ecology when people first arrived there some 13,000 years ago. As in North America (e.g., Kooyman et al. 2006), they were sometimes hunted and eaten (e.g., Alberdi et al. 2001; Steele and Politis 2009, but there is little evidence that human activity — or at least human activity alone - contributed to their eventual extinction, something that had most likely been accomplished before the start of the Holocene (Borrero 2009). Horses returned to Patagonia in the sixteenth century, introduced along multiple routes (from northwestern Argentina and, belatedly, the Buenos Aires area) by Spanish conquistadores and, from across the Andes, by the Indigenous Araucanian communities who long resisted their southward advance in Chile (Palermo 1999).

Horses, as well as the cattle that the Spanish also introduced, found much of Patagonia and the better-watered Pampas to its north ideal for their reproduction and expansion: open, disease-free grasslands that, because of the ecological thinning-out produced by mass extinctions at the Pleistocene/Holocene boundary (Borrero 2009), were deficient in dangerous predators and competing ungulates. As a result, both species were able to spread rapidly into a largely vacant and inviting ecological niche. As early as 1581 horses were noted in the vicinity of Buenos Aires (Tapson 1962). They reached northern Patagonia around 1620, and Puerto Deseado $\left(48^{\circ} \mathrm{S}\right)$ before the end of the seventeenth century, and were seen being ridden on the northern side of the Strait of Magellan in 1741 (Martinič 1995, p. 74; Martinič and Quiroz 1989/90, p. 33; Palermo 1988, p. 55). Allowing for their earlier, mid-sixteenth-century arrival in northwestern Argentina, this represents an expansion across more than $30^{\circ}$ of latitude in fewer than 200 years, one probably encouraged by the wetter, if colder conditions of the Little Ice Age (Morales et al. 2009). However, as in North America, where horses spread at a not dissimilar rate at broadly the same time (Hämäläinen 2003), this was an expansion that not only involved feral animals, but also their adoption by Patagonia's Native population. While that adoption was near-universal, it was nevertheless most pronounced in the north of Patagonia since cold and aridity made it difficult for those living south of the Río Chubut to maintain all the horses that they wished; raids and exchange compensated for this deficiency (Barceló et al. 2009; Palermo 1999). 
When asked how they had travelled before horses had become available to them, late nineteenth-century Aónik'enk - the Indigenous inhabitants of Patagonia's steppes - could not imagine that such had ever been the case (Musters 1871, p. 181). And with good reason. Horses not only made it easier for people to move around, and to do so over longer distances (Goñi 2000), they also transported people's household goods and the tents (toldos) in which they lived, even furnishing the hides from which those dwellings were made (Casamiquela 2000). In addition, horses provided an additional source of clothing (especially for boots; Martinič 1995, p. 197), offered a new dietary resource (Pero 2002, p. 110), altered the ways in which game was hunted, facilitated trade, transformed warfare, provided novel means of social aggrandisement for those who could acquire both them and the goods that they helped to circulate or obtain, and entered into myth and ritual (Mitchell 2015, pp. 278-290). In short, they transformed Aónik'enk lives, just as they did those of their Indigenous neighbours on the Pampas to the north or in the Andean foothills to the west. They continued to do so until Argentina conquered Patagonia in the so-called "Conquest of the Desert" of the late 1870s/early 1880s (Bandieri 2011; Bürgi 2008), but even now remain highly valued by Native peoples on both the Chilean and the Argentine sides of the Andes (e.g., Aguado 2006; Bacigalupo 2004).

Parallels between the transformational role of the horse in the Southern Cone and its effects on North America's Great Plains have long been noted, and with justification (e.g., Galvão 1963; cf. Hall 1998). In many respects, Aónik'enk adoption of the horse does indeed merit comparison with equestrian hunters in the United States such as the Cheyenne and Comanche. Importantly, however, things were also more complex than that. Yes, horses allowed Aónik'enk groups to hunt more effectively than before, sustain larger communities, and shift toward less egalitarian forms of social organization and gender relations. But crucially they also created the platform on which an entirely new regional economy developed and flourished in the late seventeenth, eighteenth, and early/mid-nineteenth centuries, one that knit together Chile, Buenos Aires, and the Native societies of both Patagonia and the Pampas, and became yet more complex as groups of Araucanian origin settled across the Andes in what is now Argentina. In this economy it was Indigenous populations who were its essential intermediaries and the indispensable suppliers of the key commodities-livestock, textiles, hides, and salt-flowing through it (Mandrini 1999; Palermo 1986, 1999). Such trade, and the more hierarchical social formations that it encouraged, selfevidently developed much closer to the colonial frontier, but their effects were arguably felt by Aónik'enk populations throughout Patagonia (Martinič 1995).

\section{Southern Africa}

Prior to European contact southern Africa was the culturally most diverse of the three regions I discuss. Its arid and semi-arid regions encompass four distinct biomes. Running some $2000 \mathrm{~km}$ along its Atlantic coast, the Namib Desert is the only truly arid region, with mean annual rainfall of $<150 \mathrm{~mm}$, very sparse vegetation, and no permanent rivers. Inland, the Nama-Karoo Biome reaches from central Namibia to south of the Orange River, where it covers much of South Africa's western interior. Rainfall here varies between 100 and $520 \mathrm{~mm}$ a year with vegetation mostly comprising grassy, dwarf shrublands. Westward as far as the Atlantic and reaching from 
southern Namibia to some $200 \mathrm{~km}$ north of Cape Town, the drier (20-290 mm p.a.) Succulent Karoo Biome boasts high numbers of endemic succulent plants. Finally, the extensive, mostly sand-filled basin of the Kalahari covers most of Botswana as well as eastern Namibia and north-central South Africa; its xeric grasslands once supported a much greater wealth of game than southern Africa's other drylands. The climatic structure underlying this patterning is complex, but at the risk of over-simplification the Succulent Karoo falls within the sub-continent's winter rainfall zone, the Kalahari primarily receives rainfall in summer, and the Nama-Karoo sees precipitation fall yearround. Coldwater upwelling associated with the Benguela Current is principally responsible for the Namib's hyperaridity. Hunter-gatherers had exclusive access to all these regions until the very end of the first millennium BCE when domestic livestock were introduced to the Kalahari, Namibia, and western South Africa by mechanisms that included the southward movement of people with an ultimate ancestry in East Africa (Güldemann 2008; Orton 2015). Later, the northern, eastern, and southeastern fringes of the Kalahari came to be occupied from the mid-first millennium CE by Bantu-speaking agropastoralists who combined livestock-keeping with the cultivation of summer-rainfall-demanding cereals (Huffman 2007). Bushman hunter-gatherers and Khoekhoe herders speaking a variety of click languages continued to occupy those areas too dry for mixed farming or (in the southwest of South Africa) or where rain falls in winter and sorghum (Sorghum bicolor) and pearl millet (Pennisetum americanum) cannot be grown.

Horses had long been present in northern Africa by the time the Dutch East India Company introduced them to the continent's far south in 1653, just one year after setting up a base at Cape Town. They subsequently proved an essential adjunct to the inland movement of European settlers, who had reached the Orange River, over $800 \mathrm{~km}$ northeast of Cape Town, before Britain annexed the colony in 1806. No more than in South America, however, did horses remain a purely European preserve. Ahead of the expansion of European settlers moved communities that evolved on the Cape colony's frontier from the interaction and intermarriage of Dutch-speaking colonists with Indigenous Khoe herders. One such group, the Korana, made equestrian-based hunting and raiding a keystone of their way of life as they swept across much of South Africa's Northern Cape and Free State provinces as far as the western borders of modern Lesotho. Combined with guns and wagons, horses enabled the Korana not only to raid for livestock and captives, but also to hunt elephants (Loxodonta africana) for their ivory. Ivory, salt, captives, and the meat and skins of other large game animals were then traded with European settlers for essentials that they could not produce themselves, such as firearms and gunpowder (Legassick 1989). Horses form a signature motif of the rock art that they produced (Ouzman 2005) and were an essential component of the mobility on which they and other groups, like the Griqua, depended (McShane and Swart 2011).

Equestrian raiding of this kind was not confined to South Africa. Arriving in Namibia from south of the Orange River in the late eighteenth/early nineteenth centuries, other groups of mixed cultural origins, known collectively as the Oorlam, brought with them guns and horses, and sought more of both from the Cape Colony (Kienetz 1977). Excavations and survey at //Khauxa!nas in southeastern Namibia emphasise the importance of such trade links through the impressive stone wall and entrance that greeted visitors from the south to this, the encampment of one Oorlam 
leader, Klaas Afrikaner (Kinahan 1996). Though pastoralism (of sheep and goats as much as cattle) remained critical into the 1840 s, Oorlam identity also depended heavily on the institution of the commando and its ability to mobilise mounted men armed with guns who could raid for cattle (Wallace 2011, pp. 51, 55). By the mid-1800s, the Oorlam led by Jonker Afrikaner, Klaas' grandson, dominated much of southern and central Namibia, raiding as far as the Angolan border and trading thousands of livestock to the Cape, taking captives as laborers for their own use, and dominating trade in ivory and other goods between the Kalahari and the coast (Lau 1986). Bantuspeaking Herero herders, who destroyed Oorlam hegemony in the $1860 \mathrm{~s}$, then also used guns and horses to dominate the region-and shape for themselves a newly reinforced cattle-focused pastoralist identity - in much the same way. Until weakened by drought, the exhaustion of ivory and other game, and further conflict in the years immediately preceding German colonisation, "the identification of men with guns and horses was part and parcel of a modern Herero-ness" (Henrichsen 2013, p. 220).

However, notwithstanding their importance as mounts for European settlers and groups such as the Korana, Oorlam, and Herero, horses found southern Africa a far more challenging environment than the Southern Cone. Aridity only partly explains this, since the limited rainfall characteristic of the Karoo is little different from that of Patagonia. Rather, it was because of the combination of aridity with a series of other challenges only minimally present on the Argentine side of the South Atlantic. As well as the presence of many well-established native grazing species (including zebra (Equus quagga and E. zebra) and a range of antelope, such as gemsbok (Oryx gazella), red hartebeest (Alcelaphus buselaphus), and springbok (Antidorcas marsupialis), these challenges included dangerous predators (notably lions (Panthera leo)), low quality pasture, and disease. African horse sickness presented a particularly severe problem. Caused by a virus of the same name and spread principally by midges of the genus Culicoides (though ticks and other insects can also act as vectors; Salama 1984), this disease is endemic to sub-Saharan Africa where zebras form its natural host (Wilson et al. 2009). Easily transmissible to horses, it produces mortality rates of 70-95\% (van Sittert et al. 2013). Seasonal movement of stock to avoid concentrations of Culicoides offered the only counter to infection and its presence acted as a strong constraint on the dispersal of early European colonists, as well as leaving oxen as the principal means of (wagon-borne) long-distance transport (Brown 2008; Swart 2010). Additional dangers were posed by the tendency of horses to consume toxic plants during droughts or when more palatable fodder was otherwise in short supply and - in areas with $>500 \mathrm{~mm}$ rainfall per year-their susceptibility to trypanosomiasis (sleeping sickness).

Free-living horses did not therefore establish themselves in southern Africa; the single exception - the desert horses of the Namib Desert-remain few in number, probably became feral as late as the First World War, and survive only because of the availability of man-made waterholes (Greyling 2006). The difficulties outlined above also go some way toward explaining why Bushman hunter-gatherers living on and beyond the margins of European expansion in the Karoo did not adopt horses. Though sometimes targeting settlers' horses to make pursuit more difficult, using rugged horse-unfriendly terrain as a refuge, and even exploiting outbreaks of horse sickness to launch attacks aimed at stealing other livestock, horses themselves were only rarely taken and most raids were launched on foot (Penn 2005, pp. 124, 135; van der Merwe 1988, pp. 16, 50, 84). As reflected in praise songs and horse-specific color 
terms, such knowledge as the /Xam Bushmen, for example, acquired likely derives from their participation in Korana raids as European settlement intruded ever further in the mid-1800s (McGranaghan 2012, p. 296). Only in the far-from-arid environment of the Maloti-Drakensberg Mountains of Lesotho did nineteenth-century hunter-gatherers briefly succeed in becoming equestrian raiders and keepers of livestock, profiting from a paucity of predators and competing grazers, as well as from a cooler, wetter climate that both excluded sleeping sickness and African horse sickness and supported rich grasslands (Challis 2008; Ficq 1988). The much more recent (post-1960s) acquisition of horses by some Kalahari Bushman groups to hunt game with spears derives from contact with their Bantu-speaking Kgalagadi and Tswana neighbors. However, because of the excessive time and labor costs needed to supply even one horse with sufficient water from wild tsama melons (Citrullus lanatus), this was only possible on more than the most minimal level after the drilling of artificial boreholes and once new opportunities to sell meat or otherwise acquire a cash income became available (Osaki 1984, p. 52).

\section{Australia}

Australia is the driest of the world's inhabited continents. Its deserts comprise over twothirds of its current landmass, a total area of some 3,000,000 $\mathrm{km}^{2}$ (Smith 2013), but are far from uniform as they encompass expanses of dunefields (such as the Great Sandy Desert), major upland regions (like the Pilbara of northwestern Australia), the treeless karst plain of the Nullarbor, and vast, ephemeral inland drainage basins. Temperature and rainfall vary significantly, both within and between years, but areas where precipitation is $<300 \mathrm{~mm}$ per year are considerably larger than those where it is between 300 and $500 \mathrm{~mm}$. Culturally diverse, though distinct from people living in better-watered regions of the continent (Peterson 1976), before European arrival arid zone Aboriginal peoples generally practiced opportunistic and mobile strategies that made it easier for them to take advantage of spatial and temporal variations in resource abundance. While land might be managed, for example, by controlled burning, domesticated species were restricted to the dog. Roots, tubers, and grass seeds were dietary mainstays, complemented by reptiles, marsupials, and, along the coasts, shellfish and other marine resources (Lourandos 1997).

Horses reached Australia considerably later than the other two southern hemisphere continents, arriving with the first British settlers in 1788. Even more than in South America's Southern Cone, they quickly seized the opportunities for expansion afforded by a continent completely lacking large ungulates or dangerous predators of its own. Recorded as living free in New South Wales as early as 1804, within 40 years horses had spread across Australia, typically moving faster than European settlers and explorers. In 1844, for instance, Ludwig Leichhardt saw a horse on Dawson's River in eastern Queensland, at that time $1000 \mathrm{~km}$ distant from the nearest sheep station (Reynolds 2006, p. 18). Knowledge of horses among Aboriginal communities probably spread even quicker, however, given the complex webs of exchange linking populations from one end of the continent to the other (McBryde 1987; Mulvaney 1976). The widespread diffusion of some of the terms used to describe them supports this. Yarraman, for example, which was likely invented by speakers of Dhurga living around Batemans Bay in southern New South Wales (Ramson 1966, p. 107), came to be used 
all over eastern Australia, from Cape York in the north to the Bass Strait in the far south and as far inland as Alice Springs in the continent's center (Reynolds 2006, p. 21).

As in southern Africa and the Americas, confronted with invasion Indigenous Australians sometimes removed horses from their European owners, used them to drive away livestock, and adopted strategies to impair their use as they tried to resist settler advance (Reynolds 2006). But nowhere did Aborigines secure sufficient horses to transform themselves into equestrian nomads like the Aónik'enk or mounted raiders like Lesotho's Bushmen. Instead, sustained involvement with horses came via Aboriginal recruitment into mounted police units and - on a much larger scale and mostly in the dryland regions of central and northern Australia - the sheep- (and later also cattle-) stations that spearheaded British settlement of the Australian interior (Harrison 2004; Paterson 2008). Drawing on deep knowledge of local environments, especially the location of dependable grazing and water, many Aborigines quickly learned to ride, becoming station-hands and sometimes, in the case of individuals of mixed Indigenous/ European descent, outright owners of livestock (Paterson 2005a). At the same time, sheep and cattle stations developed into new foci for the seasonal aggregation of Aboriginal communities that facilitated access to novel foodstuffs in the form of rations and to metal and glass for making tools (Paterson 2005b, 2008). Indeed, many Aborigines developed such distinctive livestock-oriented identities of their own that these are now seen by some communities as significant for maintaining traditional connections to sacred sites and landscapes and ensuring the reproduction of customary land ownership arrangements (Gill and Paterson 2007).

\section{Adopting Horses: Necessary and Sufficient Conditions}

How do these three contrasting situations - Patagonia, southern Africa, Australia - help to identify the circumstances needed for Native peoples in the drylands of the southern hemisphere to make horses the centrepiece of their lives? And, conversely, under what circumstances did they not do so, whether by choice or in its absence? I suggest that at least five variables had to come together for Indigenous populations to adopt horses on a scale large, and enduring, enough to effect significant social, economic, and political change, to become what I have elsewhere (Mitchell 2015) termed "Horse Nations."

The first of these variables, and perhaps the most crucial, was time. Acquiring horses and the skills needed to ride and raise them was not necessarily difficult in itself. In late eighteenth-century California, for instance, this took at most fourteen years (Heizer 1941). But for societies to become successfully equestrian in the sense demonstrated by the Aónik'enk demanded something more: time for horse numbers to build up (via trade, theft, and natural increase) and for their new owners to retain the political and economic autonomy needed to work out a new way of life that placed horses at its core. In Patagonia, into which horses began to spread at the end of $1600 \mathrm{~s}$, but where Euroamerican settlement outside a few tiny coastal enclaves was delayed until the 1880s (Bandieri 2011), this was clearly possible. In Australia, on the other hand, it was not (Reynolds 2006, p. 52). There, the swiftness of settler expansion and its nearcontemporaneity with the devastation wrought by epidemics such as smallpox on traditional systems of knowledge, economic production, and social and biological reproduction proved overwhelming (Kimber 1988). No uncolonized, undisturbed 
hinterlands remained free of European settlement long enough for an independent equestrian lifestyle to emerge, notwithstanding that Aborigines did sometimes take and maintain horses for their own use (Reynolds 2006, pp. 52-53). Indigenous people, in other words, therefore also needed space, space that was unattractive or impenetrable to Europeans. In Patagonia's case, Aónik'enk clearly benefitted from their homeland's sheer enormity, its aridity, and the profound logistical difficulties for small, poorly resourced colonial or republican administrations of pushing back the frontier of European settlement in the absence of repeating rifles, railways, telegraphs, and new, expansionist ideologies (Bandieri 2011; Bürgi 2008).

Such spaces, unattractive to Europeans, nevertheless had to be habitable by horses. In southern Africa disease indisputably constrained the ability even of Europeans to maintain viable horse populations in many areas (Swart 2010) and aridity and predators further compounded the problem. Conversely, where horses had once formed part of (Pleistocene) local ecologies, or where dangerous carnivores or disease-hosting ungulates were few or absent, opportunities for horses to flourish were much greater. As we have seen, large feral horse populations quickly established themselves in both Patagonia and Australia, although the differences between the two regions' histories underline how far horse-habitable space alone was from being sufficient for the development of equestrianbased societies. This leads us to another critical variable, the broader political economies of which dryland-dwelling populations formed part. One component of these was necessarily the subsistence economy that people practised at the time that horses became available to them. In the western half of North America's Great Basin, for example, Indigenous subsistence was focused on gathering. Here, then, the risk that equine demands for pasture might directly compete with the grasses and other plants on which people depended appears to have long deterred Gosiute Shoshones, and most Western Shoshones and Northern and Southern Paiutes, from adopting horses (Hurst Thomas et al. 1986; Shimkin 1986). /Xam Bushmen in South Africa's Karoo may have made a similar assessment, and in all dryland ecologies the environmental disturbance and change set in motion by the introduction of a new large ungulate species quite rapidly began to impact not just plant, but also insect, bird, and mammal communities (Beever and Brussard 2004; Beever and Herrick 2006; Nimmo and Miller 2007; Zalba and Cozzani 2004).

A second aspect of regional political economies must also be considered, namely the degree to which the geopolitical situation of particular communities, their relationships with their neighbors, and the choices made by those neighbors interacted to hinder, or facilitate, access to horses. In South Africa, for example, predominantly antagonistic relations with European settlers and mounted raiders like the Korana, for both of whom Bushmen provided exchangeable and employable captives (McGranaghan 2012; Penn 2005; van der Merwe 1988), may have left little scope for the /Xam to acquire horses of their own. Further north, in Namibia, Herero likewise used guns and horses effectively to bar other groups, like the Damara, from accessing both of these modern weapons, excluding them from trade with Europeans and forcing them into ever greater dependence on hunting and foraging (Henrichsen 2013, pp. 213, 216). Similarly, in the Gran Chaco - the extensive savannas of Paraguay, northwestern Argentina, and adjacent parts of Bolivia and Brazil - the rapid acquisition of horses by groups like the Abipones, Mbayá, and Toba blocked others, such as the Mataco, from participating in the trade with Spanish centers like Asunción and Santa Fe that might have made horses available to them as well (Métraux 1946; Palermo 1986, pp. 164, 170). 
Fundamentally, however, adopting horses (or other domesticated animals) demanded that people take the imaginative leap required, that they could fit them within a conceptual framework that allowed animals to be raised, employed, or even eaten. Even though the historical record amply demonstrates the ease with which this could happen (e.g., Tasmanians' rapid acquisition of dogs in the early 1800s; Boyce 2006), we should not assume that it was invariably so. Ethnographic work in Lowland South America, for instance, indicates that not all ontologies favor such a move, since for many Amazonian groups the ownership and "breeding" of wild animals by spirits makes it almost impossible for their long-term protection or control of their reproduction to be handed over to people, while predation (of game and other people) is essential for reproducing the self (Descola 2001, 2013; cf., Ingold 2000). Ideas like this may help explain the failure of Native equestrian adaptations to develop on the Llanos grasslands of Colombia and Venezuela (Mitchell 2015, pp. 227-231). Certainly, they imply that domesticating any animal may sometimes have required truly profound transformations of thought and culture, reminding us of the truth of Ingold's (1980, p. 143) observation that "prehistoric economic transformations cannot be described in purely ecological or technological terms." Human choice, as well as historical circumstance, must therefore be considered alongside environmental parameters in any attempt at explaining why some, but not all, Indigenous populations chose to adopt the horse in the post-Columbian world.

\section{Thinking about Horses}

Recognizing that Indigenous worldviews helped set the terms on which horses could, or could not, be adopted, reminds us that for the Native populations of all three southern continents horses were, on first acquaintance, not merely new, but also animals of previously unimaginable size and potential. Australian Aboriginal reactions were not untypical. Some thought that horse and rider were one, or that horses must be able to talk, since their riders spoke to them (Reynolds 2006, pp. 27-28). Others, like the Arabana who met John Stuart at Warriner's Creek deep in the South Australian interior in 1858, were surprised to learn that they drank, or that they could drink so much (Paterson 2005a, pp. 281-282). One way of making sense of this new and clearly powerful animal was through drawing similarities with what was already familiar. Another Aboriginal term, pindi nanto, which originated around Adelaide, but spread (as nantu) far into Australia's arid core, literally meant "the newcomer's kangaroo" (Reynolds 2006, p. 21) and made explicit reference to the biggest indigenous animal with which people were familiar. A biologically much more apt comparison was drawn by some Bushman groups in the Kalahari Desert of southern Africa: speakers of !Kung, Auen, and Nharo all made the connection with zebras, a long-familiar equid (Bleek 1956, pp. 285, 332). Further south, on the other hand, the /Xam of the Karoo (Bleek 1956, p. 156), like the Aónik'enk of Patagonia (Fernández Garay 2004), drew upon European terms: bara/para from the Afrikaans perd and kawoi from the Spanish caballo.

Rock art provides a more graphic sense of how many Indigenous populations made sense of the horse and of the power (practical and symbolic) that it offered. In each of the southern continents horses were at least partly understood through a process of assimilating them into ideas already held about species of both supernatural and quotidian 
importance. In the Southern Andean world several paintings make connections between horses and guanacos, the wild camelids that were at the core of Aónik'enk subsistence strategies and important even beyond Patagonia itself. At Parédon Lanfré south of Lake Nahuel Huapi in the Argentine foothills of the Andes, for example, what was initially the image of a guanaco was subsequently altered to take on the appearance of a horse (Podestá and Albornoz 2007). Elsewhere, particularly in northwestern Argentina, one of the first regions of the Southern Cone into which horses were introduced, paintings and engravings show horses with camelid features, such as long necks and split feet. Conversely, some guanaco/llama figures display the long tail, shorter neck, and quite different feet and ears characteristic of horses (Arenas and Martínez 2009). Sadly, however, by the time that European observers with ethnographic interests ventured into Patagonia it seems as if local rock art traditions had ended and so it is difficult to interpret precisely what significance such parallels and mergers were intended to convey.

Representations of horses in Aboriginal Australian art should, in principle, be easier to grasp, since in many parts of the continent there is much greater continuity in rock art production down to the present. The Black Horse Rider Gallery at Laura, Queensland, recalls Parédon Lanfré in that the horses depicted there clearly derive from earlier experience with painting kangaroos: they show, for example, not only a generalized marsupial-like silhouette, but also in at least one case the shortened forearms typical of kangaroos (Macropus spp.) and wallabies (Macropus spp., Onychogalea spp., Petrogale spp., Thylogale spp., Wallabia bicolor). Alternatively, kangaroo images have been modified to accommodate horse-like tails, muzzles, hoofs, and ears (Rosenfeld 1982). Consistent perhaps with the initial difficulty for many Native peoples of discriminating between horse and rider, riders, when shown, often appear to be standing on their horse's back, or merging into it, rather than sitting in any realistic fashion. But while the images at Laura can be understood in terms of people attempting to make sense of the new within the bounds of the familiar, and may indeed have had some kind of ceremonial or ritual associations, others are patently secular. Indeed, the artist responsible for the horse depicted in a rockshelter on Bickerton Island off Australia's north coast explicitly stated that it was painted to show other people how the animal looked (Turner 1973). Most representations of horses, however, especially in central and northern Australia, are associated with evidence of commercial livestock production and occur close to images of European men, guns, and livestock (Layton 1992). Unlike more traditional imagery, this art is often in plain view and thus unlikely to have held profound spiritual significance. On the other hand, it is noteworthy that while much Aboriginal involvement centred on the care of sheep, it is the much more powerful horse that was singled out for commemoration in rock art (Paterson 2008, pp. 194, 196; 2012).

Southern Africa presents something of a paradox for any discussion of how horses were represented since the Kalahari offers very few suitable surfaces for the production of rock art, Botswanan and Namibian hunter-gatherers have no surviving rock art tradition, and even in the Karoo rock engravings stopped being produced at least one full generation before our only detailed ethnohistoric records were made in the 1870s (Deacon 1986). Horses are, however, prolifically represented in the paintings produced in the Maloti-Drakensberg Mountains further to the east in the middle decades of the nineteenth century. The subject of several major studies, most recently by Sam Challis (2008), they unequivocally demonstrate the assimilation of horses with eland (Campbell 1987, pp. 87-90), one of the most powerful animals in Bushman cosmologies, and 
with hippopotami (Challis 2008, p. 281). Linking these three quite different taxa together were beliefs that conceptualized the rain as an animal that might be captured and killed (by shamans in altered states of consciousness, but perhaps also sometimes in ritual). Horses, in other words, may have become rain-animals, but (when shown being used to hunt eland) could be the means by which rain-animals could be intercepted and killed. Other paintings suggest that horses were also construed as sources of the supernatural potency that shamans could access in trance to heal the sick and forestall illness in others (Campbell 1987; Challis 2008). Moreover, a single reference to men painting with brushes made from horsehair raises the possibility that their spiritual significance carried over into the very production of the art itself (Mitchell 2006/07). Regrettably, we lack evidence that any of these connotations were shared by the /Xam Bushmen of the Karoo, though we do know that horses were considered to be "praiseworthy" animals and that their reins (bara-ka-!hau!hau "horse's thongs"; Bleek 1956, pp. 156, 396) evoked the power of shamans to bind and ride rain-animals and thereby ultimately render them useful (McGranaghan 2012, pp. 296-297).

\section{How Horses Changed What People Ate}

If how horses were imagined and understood identifies one theme for comparative study across southern hemisphere drylands, then their impact on what people ate and how they obtained food provides another. The evidence is strongest in Patagonia, where exploitation of seals, sea lions, and marine shellfish declined sharply after horses became available and what had, in some cases, been year-round occupation of the coastline became much more ephemeral, matching historical accounts that suggest little continuing use of coastal resources. Stable isotope analysis of human remains confirms that at least to the north of the Río Chubut $\left(\sim 43^{\circ} \mathrm{S}\right)$ equestrian-era diets came to include a much greater quantity of terrestrial protein (Gómez Otero 2007b; Gómez Otero and Novellino 2011; Moreno and Videla 2005).

Any explanation of these changes is likely to involve at least three factors. First, how people obtained meat altered once horses could be used to locate and chase game. Thus, Aónik'enk abandoned the use of the bow-and-arrow, substituting instead another technology, the bolas, stone spheres tied to leather straps that were launched by hand and are known in several versions (Cirigliano 2011; Hernández 2002). More effective than bows when riding, bolas were formidable weapons, able to reach a precise target almost $60 \mathrm{~m}$ away and capable of bringing down horses as well as other game, notably guanaco, the principal prey of Patagonian hunters. Using horses, people could now more readily surround and ride into guanaco herds, allowing hunters to kill or disable them with ease. "Of use in every way" (Musters 1871, p. 132), Aónik'enk not only ate guanaco meat and fat, but used their sinews to make thread, their hides for tents (toldos) and clothing, their skin for lassoes, thongs, and bolas straps, and even their bones for items such as dice and flutes. In all respects they formed a Patagonian equivalent of the role played by bison (Bison bison) on North America's Great Plains, even to the extent of drying, roasting, and pounding the meat so that it could be stored, mixed with grease, for later use, just like pemmican. Guanaco were not, however, the only game that people pursued, and it seems likely that adoption of the horse made it considerably easier for hunters to acquire not just them, but also rhea (Fernández 2008; 
Giardina 2010), neither species of which occurs more than sporadically in pre-Hispanic faunas from northern or central Patagonia (Ramiro Barberena, pers. comm.). Changes in what could be hunted therefore likely form a second component of the changes observed in regional settlement pattern during the post-contact period.

A third and final element springs from the greater mobility that horses made possible and from the fact that, just as on North America's Plains, people who kept horses also had to accommodate themselves to their animals' needs. On the one hand, horses allowed people to range further, most likely by facilitating a shift to a more logistical pattern of mobility, while reducing the number of times a year that groups had to shift location (Goñi 2000; Martinič 1995). On the other, they required adequate pasture and shelter from cold Patagonian winters. Thus, at the local level along the Río Senguer in Chubut province, sites post-dating European contact are mostly found some 5-10 km upstream than those of earlier date, and close to fords and in areas that remain free from flooding (and thus available for grazing) when snows melt in the spring (Aguado 2006). Greater logistical mobility - associated in this case with incipient herding and an enhanced degree of sedentism - is evident in the Río Cisnes area of the central Patagonian Andes (Velásquez et al. 2007) and is also implied by changes in stone tool use at sites likely used only in summer around Laguna Condor in Argentina's Santa Cruz province in the far south of Patagonia (Charlin 2012).

One component of these changes warrants additional attention since huntergatherers living in Patagonia are always likely to have confronted the challenge of a high protein/low fat diet, at least during winter/spring when human calorific demands increased (in order to keep warm) and the body fat levels of their principal preyguanaco-were lowest (Bourlot 2006). The adverse nutritional and metabolic consequences of such a situation are well known, as are the possible means by which people can cope with it: storing fat for later use; putting on body fat; increasing exploitation of fat-rich taxa or individuals; intensifying use of carbohydrates, obtained either through gathering or via exchange with others, usually farmers (Speth 1983, 2010; Speth and Spielmann 1983). Patagonia's archaeology indicates that its inhabitants persistently tackled this issue by smashing up animal bones in order to extract from them the marrow (Fernández 2008), the principal location of fat in both guanaco and another important prey species, the huemul deer (Hippocamelus bisulcus) (De Nigris 2004). Boiling bone to extract grease from it is also likely to have been practiced, at least after the adoption of pottery within the last 1200 years. Compounding the problem still further, however, was the fact that guanaco meat has particularly low levels of some of the fatty acids, such as linoleic and $\alpha$-linolenic acids, essential to human health (Sadoun and Cabrera 2008). Coincidentally, it is precisely these fatty acids that are well represented in the meat of horses (Levine 1998). That Aónik'enk consumed horsemeat is well known, and even though the context for this often seems to have been a ritual one, the opportunities to do so were far from uncommon: curing the sick, marriage, girls' puberty rituals, death, escapes from danger, the experience of injury, or even naming or enquiring after the dead all required the sacrifice of one or more horses. Strikingly, too (and perhaps surprisingly given that Aónik'enk were far from horserich), the animals concerned were female: intriguingly, while differences in the nutritional content of the meat of male and female horses have often been considered minimal (Tateo et al. 2008), other studies indicate that female animals offer a slightly higher fat content (Dobranić et al. 2009). Supporting the argument that horsemeat 
consumption (and especially that of mares' meat) may have had a nutritional dimension to it, it is precisely the meat of young mares, rich in fat and tender, that is preferred by central Eurasian nomads such as the Yakuts and Kazakh (Ferret 2010). That horses made it easier for people to kill rheas now acquires yet further significance, since their meat was preferred to that of guanacos precisely because of its greater fat content: Musters (1871, p. 77), for example, notes that rhea marrow and the fat from their thighs and eyes was "eaten with great gusto"! On multiple levels, then, on the drylands of Patagonia horses changed what people ate and how they found food.

The absence of any autonomous development of an equestrian-based lifestyle in arid zone Australia limits the possibilities for comparison between that continent and Patagonia. However, Botswana's Central Kalahari Game Reserve provides an ethnographically documented instance of how adopting the horse can change hunter-gatherer hunting strategies. Here, as noted above, G/wi and G//ana Bushmen in the Kade area of the central Kalahari adopted mounted hunting in the 1970s and 1980s. As a result they were able to expand the range over which they could move, reduce the time needed to find and kill animals, chase, tire, and overtake several key species, such as eland (Tragelaphus oryx), and make it easier to transport sun-dried meat back to camp. Since all ethnographically described Bushman bows are really no more than delivery devices for poisoned darts that can - in the case of a large mammal-take days to kill, horses also allowed the bow and arrow to be replaced by a close quarters weapon, the spear; tracking wounded animals was thus also rendered unnecessary (Osaki 1984). Numerous rock paintings in the Maloti-Drakensberg Mountains attest to similar transformations of hunting practice there in the mid-1800s (e.g., Vinnicombe 1976, pp. 288-289).

Data presented by Osaki (1984) suggest that after men began to hunt from horseback their hunting range increased by around $25 \%$, while longer-distance hunting expeditions of a more logistical character also became increasingly possible (using donkeys, rather than horses, as beasts of burden for returning meat to camp). Importantly, however, changes in hunting practice also had social consequences. For example, several large animals might be killed in a single hunting trip, something previously impossible. Since the animals acquired belonged to the owner of the horse used to kill them, and not all hunters owned their own horses, some individuals were also able to obtain much greater amounts of meat. Although sharing meat continued to be socially enforced, its redistribution became increasingly concentrated among close relatives and intimate friends of the horse owner, the successful hunter (where they were not one and the same), and those assisting him. Differential access to horses (which made any expectation of reciprocity from non-horse owners doubtful at best), coupled with opportunities to sell meat to non-Bushmen and the impossibility of even the largest kills satisfying the needs of everyone in the new, permanent settlement in which people now lived, thus undercut a key component of traditional egalitarianism (Osaki 1984, pp. 59-60). On a much larger scale, and probably starting from a socially less equal base, differential access to horses and to the food that they could provide also facilitated the emergence of increasingly profound social differences in other post-Columbian equestrian societies, notably on North America's Great Plains (e.g., Biolsi 1988, p. 159; Hämäläinen 2003, p. 850). 


\section{"Cowboys and Indians"}

In all three southern hemisphere continents the horse proved to be the harbinger of European colonization and the eventual conquest, displacement, and at least partial assimilation of their Indigenous inhabitants by the modern nation-state. The transition from autonomy to incorporation is particularly suited to investigation through a combination of textual and material sources, with considerable recent research taking place in both Australia and Argentina. In the latter, for instance, excavations at twentieth-century sites in the Lake Strobel and Coyle regions of Santa Cruz province, in the far south of Patagonia, document the continuing persistence of traditions of making stone tools (including bolas), alongside their expansion to encompass new raw materials - bottle glass and porcelain - that were preferred for making hide scrapers (Belardi et al. 2013; Carballo Marina et al. 2011; Nuevo Delaunay 2012, 2013). Australian archaeology, of course, has long documented a similar use of glass and porcelain as part of a more general adoption by Indigenous people of elements of European diet and technology (e.g., Harrison 2003; Paterson 2005b).

The link between horses and livestock-rearing itself defines another commonality between Patagonia and Australia, and in different ways (e.g., because it is not universally dominated by groups of European descent) southern Africa too. To use a wellknown cliché, the relationship between "Cowboys" and "Indians" merits attention not only in terms of conflict before European conquest was completed, but also in terms of their mutual contribution to the emergence of locally distinctive livestock-oriented cultures then and thereafter (Dyck 1996; Slatta 1990). Argentina's gauchos, for instance, show multiple cultural borrowings from Indigenous groups: hunting with bolas, wearing ponchos (a trademark-and widely traded - product of pre-colonial Patagonians and their Araucanian and Pampas Indigenous neighbours), using a wrapped, woollen chiripá instead of trousers, drinking mate tea, and even employing Native terms for the horse itself (bagual). Archaeological excavations add to this the possibility of learning how to make stone scrapers for working wood and leather (Romero and Spota 2006). Like the huasos of Chile, the llaneros of Colombia and Venezuela, and even the cowboys of North America, gauchos also frequently shared with Indigenous populations the disdain and denigration of sedentary, urban, centralising elites keen to tame or remove them in the pursuit of building the state (Duncan Baretta and Markoff 1978).

As Alistair Paterson (2008), Rodney Harrison (2003, 2004), and others have shown, the evolution of commercial livestock production in the Australian Outback also depended heavily upon the labor, adaptability, and expertise of Aboriginal stockmen (and women). Their detailed knowledge of local environments was particularly important. As in Patagonia, the seasonal nature of much livestock work nevertheless meant that when European demands for labor were low it was possible - at least to some degree - for Aborigines to maintain traditional ritual, ceremonial, and exchange activities and campsites of their own. Even though the greater ease with which younger men could find employment, access European goods, and learn the new skills that caring for sheep and cattle demanded could threaten the social standing of their elders (Reynolds 2006, p. 52), it nevertheless offered Outback-dwelling Aborigines a means of retaining partial economic and cultural autonomy, something denied to many of their fellows in those areas of Australia more densely settled by Europeans. Some southern African 
Bushman groups, too, found opportunities for physical survival, if not autonomy, in becoming an essential workforce for predominantly Afrikaner farm-owners. The Nharo of western Botswana's Ghanzi District (Guenther 1986), the Ju/'hoãnsi of Namibia's Omaheke District (Sylvain 2001), and the /Xam of South Africa's Northern Cape Province (now long assimilated into an Afrikaans-speaking Colored rural proletariat; Traill 1996) all exemplify this. Other Bushman descendants, the Karretjiemense ("[Donkey] Cart People"), survive in the Karoo as itinerant farm laborers and sheep-shearers (De Jongh 2012). None of these groups has yet received significant archaeological attention, but all contributed to European acquisition of knowledge about local geography, animal behavior, and resources such as water and wild plant foods (McGranaghan 2012, pp. 359-360; Sylvain 2001, p. 731), something memorialized in surviving place names (e.g., Deacon 1988, p. 134; Humphreys and Thackeray 1983, p. 27).

\section{Equestrian Adaptations in Southern Hemisphere Drylands}

The drylands of Patagonia, the Karoo, the Kalahari, and Australia were far from the only parts of the post-Columbian "new worlds" into which Europeans introduced, or returned, horses after 1492. Famously, of course, they did so in North America, where novel equestrian adaptations developed in the southwestern United States (Clark 2001) and the Great Plains (e.g., Ewers 1955), but also west of the Rocky Mountains around the Columbia River, among some of the Ute and Shoshone groups of the Great Basin, and in the Central Valley of California (e.g., Phillips 1993). Further afield, horses revolutionized life for the Wayúu of the La Guajira peninsula of Colombia/Venezuela (Picon 1983), the inhabitants of the Gran Chaco (Saeger 2000), the Native populations of the Pampas of Argentina and Uruguay and the Araucanians of Chile (Jones 1999), and yet others in eastern Bolivia (Saignes 1985) and highland Lesotho (Challis 2008). Even New Zealand's Māori were not exempt (Mincham 2008). To ask how far the equestrian adaptations that developed in the southern hemisphere's drylands differed from those found elsewhere is material for another paper. So, too, is detailed consideration of several other themes ripe for comparative treatment, such as the role of horses in facilitating the emergence of more hierarchical forms of social (including gender) relations, the special kinds of equipment that their use and care demanded, and their impacts on the ecologies into which they entered, not least because of the possibility that such impacts helped undermine the very lifestyles to which it gave rise (e.g., Isenberg 2000).

We can nevertheless identify some ways in which the impact of the horse varied between Patagonia, southern Africa, and Australia. Most obviously, Aboriginal involvement with and use of horses in Australia occurred almost exclusively in the context of European-dominated ranching. In contrast, the same phenomenon followed up to two centuries or more of Native equestrian use in Patagonia. Just as in Australia, however, southern African dryland hunter-gatherers found little use for the horse, with late twentieth-century employment in parts of the Kalahari likely to prove a passing phenomenon. In contrast, horses proved vital for the expansion of novel, maraudingand trading-based communities of mixed European and Native pastoralist origin, such as the Korana and Oorlam. Beyond the $500 \mathrm{~mm}$ isohyet they also empowered hunter- 
gatherers in Lesotho's mountains to maintain a short-lived existence that likewise combined raiding and trading with keeping livestock of their own. Both situations merit comparison with areas beyond southern Africa, but neither saw the long-term enmeshment of autonomous Native equestrians with the broader colonial economy that marked northern Patagonia, the Pampas, and Araucanian Chile. Of the three dryland regions I have compared, it is thus Patagonia that stands out for the longevity of its Indigenous equestrian societies and for the transformational impacts that the horsethough not it alone (Mandrini 1999, p. 50)-brought about. These differences, along with observations from elsewhere, act as a springboard for asking how far adopting the horse therefore entailed a different history of contact and eventual colonization compared to those who were unable, or who chose not, to do so.

Any answer to this question has to have due regard to human agency, to the specific, contextual decisions of particular groups of people in particular political, economic, and fast-changing situations. Even if we cannot identify even the outlines of the social calculus or belief systems in which those decisions were taken, at least part of the explanation for why some groups adopted the horse and others did not must lie here: its non-adoption by the other inhabitants of La Guajira, some from the same cultural and linguistic background as the ancestors of the Wayúu who rapidly adopted not only horses but also cattle, sheep, and goats (Polo Acuña 1999), offers one instance of this. A second comes from the Colorado/Gila River area immediately north of the Gulf of California, where Cocopas took to horses eagerly, using them to raid for slaves whom they could sell to the Spanish and Mexicans, while their Quechan neighbors proved far more wary (Zappia 2008).

On a larger scale, however, it is worth emphasizing again how the very aridity of deserts and semi-deserts may have shaped Native equestrianism. First, and most important, horses have specific demands. No more than any other animal (or plant) do they constitute a tabula rasa with which people can do as they please. Critical considerations include the inefficiency of their digestive system compared to ruminants, which requires them to consume much larger amounts of food ( $2 \%$ of body mass per day; $5 \%$ for lactating mares) and means that this must be abundant, particularly when it is of limited quality or high in fiber (Landals 2004; Menard et al. 2002); the need when working, or when eating dry grass, for almost all (85-90\%) their water intake to come in liquid form; their intolerance of algae-rich, polluted, or mineral-deficient water sources; and their limited ability to survive severe cold without adequate shelter (Cymbaluk 1999; Landals 2004).

With few exceptions (Landals 2004; Osborn 1983; Rinn 1975) the archaeological literature even in North America has not yet grappled with how people did, or did not, adopt the horse within the matrix created by this intersection of equine biology, regional ecologies, and human social and dietary needs and desires, let alone the means by which the requisite knowledge was transmitted, or relearned, to ensure that horsekeeping was viable. At a very preliminary level, however, it is possible to outline some of the parameters that might be investigated. First, where water and grazing were scarce, or highly unpredictable in time and space, people's ability to keep horses in large enough numbers to make an equestrian lifestyle possible was severely constrained: arid zone Australia and southern Africa's Kalahari and Karoo exemplify this well given their extreme paucity of permanent water sources before the advent of boreholes and wind pumps in the late nineteenth century. Specifically in southern 
Africa predators and parasites constituted further problems. Second, even where horses could survive if Indigenous populations based their subsistence primarily on plant foods, then, as I indicated earlier, they may have been reluctant to adopt them if this risked damaging the very resources on which they depended, either directly or through equine modification of local ecologies. Such constraints will not have applied, however, where, as in large parts of Patagonia, permanent rivers and lakes provided dependable sources of water, dangerous carnivores and diseases were few or absent, and plants were less important in people's diets.

On the other hand, the availability of concentrated, predictable resources that could be better exploited from horseback than on foot likely provided a compelling incentive to take to the horse. In both the Karoo/Kalahari and arid Australia, mammalian resources were typically wide-ranging, if not migratory, in their movements. In Patagonia, on the other hand, guanaco, the principal prey of the Aónik'enk, are - except for large, all male groups - highly territorial, and even where migratory have home ranges that are no more than 20-50 km across (Garrido et al. 1981). Irrespective of whether mounted hunters could more readily locate wandering males, horses made it much easier to surround, target, and procure whole groups of guanaco - and probably of rhea too (Fernández 2008). Comparably dense and spatially predictable resource concentrations did not exist in either southern African or Australian drylands, but for Korana, Oorlam, and Herero raiders did plunder and trade in ivory, meat, captives, and skins (i.e., partial integration with the expanding colonial economy of the Cape) provide a viable substitute? The example of northern Patagonia's incorporation into a broader regional economy trafficking livestock, hides, textiles, and other produce to and between colonial markets in Chile and Buenos Aires suggests that it may (e.g., Henrichsen 2013).

This leads to a further point, the broader context of European expansion. Only rarely (e.g., Spanish New Mexico; Spicer 1962) were arid and semi-arid regions singled out for settlement. Such areas therefore tended to remain available to Indigenous populations, for whom they offered refuge from military interventions and the possibility of continued political and economic autonomy. Where this was so and horses could also thrive created the conditions necessary for Indigenous adoption of the horse to become possible. In Australia, colonization (and the epidemics arriving with it) happened too swiftly. In southern Africa, predators, disease, and a paucity of permanently dependable water sources precluded the autonomous emergence of equestrian-based societies except in the limited case of groups like the Korana or, in the better-watered areas of the Namibian interior, the Oorlam and Herero. Conversely, in much of Patagonia - as in the Gran Chaco (Saeger 2000) where access to water was less pressing distance from the centers of European settlement, and the highly limited capacity of pre-industrial states successfully to penetrate dryland regions and bring their power to bear within them, kept Europeans out long enough. Such places became even more favorable for the emergence of equestrian societies where Indigenous populations also gained access to new sources of food (such as feral cattle or, notably in Chile and the north of Patagonia, domestic livestock), and where profitable opportunities existed for trade with - and raids against - colonial societies. La Guajira provides a mirror image of this situation in the far north of South America (Picon 1983), the history of the Apache and Navajo another in the southwestern United States (Clark 2001). Parallels with the "Great American Desert" of North America (Dillon 1967) are also striking, but not a surprise since the High Plains of Canada and the United States are an area of semi-arid grassland par excellence, and, like much of Patagonia or the Chaco, ideal 
terrain for the horse. Similarities and differences in their respective post-Columbian equestrian adaptations invite further investigation.

Two final observations. First, this paper should be read as no more than a partial contribution to wider studies of the introduction to southern hemisphere drylands of animals that opened up new opportunities for settlement and subsistence to Indigenous societies and incoming European settlers alike: camels and donkeys, for example, have rightly received attention in both Australia and southern Africa (McKnight 1969; Jacobs 2001; Smith and van Schalkwyk 2002; Bough 2011; Crowley 2014). Second, its primary focus has lain with societies that were hunters and gatherers at the time they became acquainted with the horse. While in all three southern continents such communities were incorporated, often involuntarily, into commercially oriented livestock operations structured around European concepts of the private ownership of both land and animals (ranching, sensu Ingold 1980), this kind of "pastoral domain” (Paterson 2008, p. 19) was only one outcome of the horse's introduction. If, however, following Ingold (1980), we define pastoralism as dependence on the husbandry of one or more large domesticated animals combined with their incorporation into human social relationships-whether as bridewealth payments, media for storing wealth, capital for political action, or reservoirs of supernatural potency - and note also the constraints that the ecological needs of animals place on people and their movements (Smith 2005, p. 23), then another, even more exciting, comparative vista opens up. For on these grounds there is surely little to divide post-Columbian equestrian societies in Patagonia, southern Africa, and many other regions from pastoralists elsewhere just because they rode horses to hunt (raid, trade, fight, move etc.) rather than to herd livestock (even where these were kept, for example by Oorlam and Herero). Writing of the North American Plains, Atwood Lawrence (1985, p. 9) notes that, "Nuer cattle are the essential food supply, whereas Plains horses were essential to the food supply, but in both cases the animals represent the most important social asset" and that because "it was the intermediary animal and not the food animal which was herded does not preclude looking upon Plains tribes as pastoralists" (see also Betty 1997; Hämäläinen 2008, pp. 315-318; Mishkin 1940; Ponomarenko and Dyck 2007). Comparative study of those societies living in the drylands of the southern hemisphere that acquired horses after 1492 is not only worthwhile in itself, but would also enrich investigations of nomads and pastoralists in that Old World whose enmeshment with the global South was a consequence of Columbus' voyage.

Acknowledgments I am grateful to the editors and to two anonymous reviewers for comments that improved the original draft of this paper and to Rachel King for the map that accompanies it.

Open Access This article is distributed under the terms of the Creative Commons Attribution 4.0 International License (http://creativecommons.org/licenses/by/4.0/), which permits unrestricted use, distribution, and reproduction in any medium, provided you give appropriate credit to the original author(s) and the source, provide a link to the Creative Commons license, and indicate if changes were made.

\section{References}

Aguado, A. (2006). Los pueblos originarios (históricos) en el departamento Río Senguer, suroeste del Chubut. In Actas II Seminario Un Encuentra con Nuestra Historia, Sociedad de Historia y Geografia de Aisén y Municipalidad de Coyhaique, Coyhaique, pp. 58-68. 
Alberdi, M. T., Miotti, L., and Prado, J. L. (2001). Hippidion saldiasi Roth, 1899 (Equidae, Perissodactyla), at the Piedra Museo site (Santa Cruz, Argentina): its implication for the regional economy and environmental reconstruction. Journal of Archaeological Science 28: 411-419.

Arenas, M. A., and Martínez, J. L. (2009). Construendo nuevas imágenas sobre los otros en el arte rupestre andino colonial. Revista Chilena de Antropología Visual 13: 17-36.

Atwood Lawrence, E. (1985). Hoofbeats and Society: Studies of Human-Horse Interactions, Indiana University Press, Bloomington.

Bacigalupo, A. M. (2004). The struggle for Mapuche shamans' masculinity: colonial politics of gender, sexuality and power in southern Chile. Ethnohistory 51: 489-533.

Bandieri, S. (2011). Historia de la Patagonia, Editorial Sudamericana, Buenos Aires.

Barceló, J. A., del Castillo, M. F., Mameli, L., Moreno, E., and Videla, B. (2009). Where does the south begin? social variability at the top of the world. Arctic Anthropology 46: 50-71.

Beever, E. A., and Brussard, P. F. (2004). Community- and landscape-level responses of reptile and small mammals to feral-horse grazing in the Great Basin. Journal of Arid Environments 59: 271-297.

Beever, E. A., and Herrick, J. E. (2006). Effects of feral horses in Great Basin landscapes on soils and ants: direct and indirect mechanisms. Journal of Arid Environments 66: 96-112.

Belardi, J. B., Carballo Marina, F., Nuevo Delaunay, A., and de Angelis, H. (2013). Raspadores de vidrio y de gres cerámico en la reserva Tehuelche (Aonikenk) de Camusu Aike: aportes al conocimiento de poblaciones indígenas de los siglos XIX y XX en el territorio de Santa Cruz. Relaciones de la Sociedad Argentina de Antropología 38: 37-57.

Betty, G. (1997). "Skilful in the management of the horse": the Comanches as Southern Plains pastoralists. Heritage of the Great Plains 30: 5-13.

Biolsi, T. (1988). Ecological and cultural factors in plains Indian warfare. In Ferguson, R. B. (ed.), Warfare, Culture and Environment, Academic Press, Orlando, pp. 141-168.

Bleek, D. F. (1956). A Bushman Dictionary, American Oriental Society, New Haven.

Borrero, L. A. (2009). The elusive evidence: the archaeological record of the south American extinct Megafauna. In Haynes, G. (ed.), American Megafaunal Extinctions at the End of the Pleistocene, Springer, New York, pp. 145-168.

Borrero, L. A., Barberena, R., Franco, N. V., Charlin, J., and Tykot, R. H. (2009). Isotopes and rocks: geographical organisation of southern Patagonian hunter-gatherers. International Journal of Osteoarchaeology 19: 309-327.

Bough, J. (2011). Donkey, Reaktion Books, London.

Bourlot, T. (2006). El consume de grasa en la dieta de poblaciones cazadoras-recolectoras del interior de la estepa patagónica. Novedades de Antropología 54: 3-6.

Boyce, J. (2006). Canine revolution: the social and environmental impact of the introduction of the dog to Tasmania. Environmental History 11: 102-129.

Brown, K. (2008). Frontiers of disease: human desire and environmental realities in the rearing of horses in nineteenth and twentieth-century South Africa. African Historical Review 40: 30-57.

Bürgi, S. (2008). La Conquête du 'Désert' Argentin (1879) et la Fin de la Question Indigène, Etude sur une Justification Idéologique d'une Spoliation, Mémoire de License, University of Lausanne, Lausanne.

Campbell, C. (1987). Art in Crisis: Contact Period Rock Art in the South-Eastern Mountains of Southern Africa. Master's thesis, University of the Witwatersrand, Johannesburg.

Carballo Marina, F., Belardi, J. B., and Sáenz, J. L. (2011). Distribución especial del registro arqueológico en la unidad de paisaje terrazas, cuenca media del Río Coyle (provincia de Santa Cruz, Argentina). Magallania 39: 207-222.

Casamiquela, R. (2000). Temas patagónicas de interés arqueológico VI: análisis etnográfico de la morfología del toldo tehuelche y sus derivaciones etnológicas (hacia una "retro-etnología"). Intersecciones en Antropología 1: 3-33.

Challis, W. (2008). The Impact of the Horse on the AmaTola "Bushmen": New Identity in the MalotiDrakensberg Mountains of Southern Africa. Doctoral dissertation, University of Oxford, Oxford.

Charlin, J. E. (2012). Materias primas líticas y uso del espacio en las nacientes del río Gallegos: el caso de laguna Cóndor (estancia Glencross, Santa Cruz, Argentina). Magallania 40: 163-184.

Cirigliano, N. A. (2011). Materias primas líticas y cronologías de puntas pedunculadas tipo Fell V entre las cuencas de los ríos Chico - curso inferior y medio - y Santa Cruz (provincia de Santa Cruz). La Zaranda de Ideas: Revista de Jóvenes Investigadores en Arqueología 7: 9-22.

Clark, L. H. (2001). They Sang for Horses: The Impact of the Horse on Apache and Navajo Folklore, University of Arizona Press, Tucson.

Crosby, A. W. (1986). Ecological Imperialism: Biological and Cultural Consequences of 1492, Cambridge University Press, Cambridge. 
Crosby, A. W. (2003). The Columbian Exchange: Biological and Cultural Consequences of 1492, Greenwood, Westport.

Crowley, S. L. (2014). Camels out of place and time: the dromedary (Camelus dromedarius) in Australia. Anthrozoös 27: 191-203.

Cymbaluk, N. (1999). Water: the overlooked nutrient. Proceedings of the 1999 Horse Breeders and Owners Conference, Alberta Agriculture, Food and Rural Development, Edmonton. http://www.distanceriding. org/php/articles/nutrition/Water.pdf Site accessed 25 July 2014.

De Jongh, M. (2012). Roots and Routes: Karretjie People of the Great Karoo. The Marginalisation of a South African First People, University of South Africa Press, Pretoria.

De Nigris, M. E. (2004). Guanaco and huemul in Patagonian hunter-gatherers' diet. In Mengoni Goñalons, G. L. (ed.), Zooarchaeology of South America, British Archaeological Reports, Oxford, pp. 11-37.

Deacon, J. (1986). "My place is the Bitterpits": the home territory of Bleek and Lloyd's/Xam San informants. African Studies 45: 135-155.

Deacon, J. (1988). The power of a place in understanding southern San rock engravings. World Archaeology 20: $129-140$.

Der Sarkissian, C., Vilstrup, J. T., Schubert, M., Seguin-Orlando, A., Eme, D., Weinstock, J., Alberdi, M. T., Martin, F., Lopez, P. M., Prado, J. L., Prieto, A., Douady, C. J., Stafford, T. W., Willerslev, E., and Orlando, L. (2015). Mitochondrial genomes reveal the extinct Hippidion as an outgroup to all living equids. Biology Letters 11: 20141058.

Descola, P. (2001). The genres of gender: local models and global paradigms in the comparison of Amazonia and Melanesia. In Gregor, T. A., and Tuzin, D. (eds.), Gender in Amazonia and Melanesia: An Exploration of the Comparative Method, University of California Press, Berkeley, pp. 91-114.

Descola, P. (2013). Beyond Nature and Culture, University of Chicago Press, Chicago.

Dillon, R. H. (1967). Stephen Long's Great American Desert. Proceedings of the American Philosophical Society 111(2): 93-108.

Dobranić, V., Njari, B., Mioković, B., Cvrtila Fleck, Ž., and Kadivc, M. (2009). Chemical composition of horse meat. Meso 11: 62-67.

Duncan Baretta, S. R., and Markoff, J. (1978). Civilization and barbarism: cattle frontiers in Latin America. Comparative Studies in Society and History 20: 587-620.

Dyck, I. (1996). Does rodeo have roots in ancient Indian traditions? Plains Anthropologist 41: 205-219.

Ewers, J. C. (1955). The Horse in the Blackfoot Indian Culture with Comparative Material from other Western Tribes, Smithsonian Institution, Washington DC.

Fernández, P. M. (2008). Taphonomy and zooarchaeology in the Neotropics: a view from the northwestern Patagonian forest and steppe. Quaternary International 180: 63-74.

Fernández Garay, A. V. (2004). Diccionario Tehuelche-Español, University of Leiden Press, Leiden.

Ferret, C. (2010). Une Civilisation du Cheval: Les Usages de l'Equidé de la Steppe à la Taiga, Belin, Paris.

Ficq, C. J. (1988). Die Betekenis van Perde in die Bewoning van die Lesotho-Hoogland. Master's thesis, Randse Afrikaanse Universiteit, Johannesburg.

Galvão, E. (1963). O cavalo na América indígena: nota previa a um estudo de mudança cultural. Revista do Museu Paulista 14: 222-232.

Garrido, L. J., Amaya, J. N., and Kovacs, Z. (1981). Territorialidad, Comportamiento Individual y Actividad Diaria de un Población de Guanacos en la Reserva Faunistica Cabo Dos Bahías, Centro Nacional Patagónico, Puerto Madryn.

Giardina, M. A. (2010). Human exploitation of Rheidae in north Patagonia, Argentina (South America). In Prummel, W., Zeiler, J. T., and Brinkhuizen, D. C. (eds.), Birds in Archaeology: Proceedings of the 6th Meeting of the ICAZ Bird Working Group in Groningen (23.8-27.8.2008), Barkhuis, Groningen, pp. 97102.

Gill, N., and Paterson, A. G. (2007). A work in progress: the past, present and future of indigenous pastoral heritage. In Jones, R., and Shaw, B. (eds.), Loving a Sunburned Country? Geographies of Australian Heritage, Ashgate, Aldershot, pp. 113-131.

Gómez Otero, J. (2007a). Dieta, Uso del Espacio y Evolución en Poblaciones Cazadoras-Recolectoras de la Costa Centro-Septentrional de Patagonia Durante el Holoceno Medio y Tardio. Doctoral dissertation, Universidad de Buenos Aires, Buenos Aires.

Gómez Otero, J. (2007b). Isótopos estables, dieta y uso del espacio en la costa atlántica centro septentrional y el valle inferior del río Chubut (Patagonia argentina). In Morello, F., Martinič, M., Prieto, A., and Bahamondes, G. (eds.), Arqueología de Fuego-Patagonia: Levantando Piedras, Desenterrando Huesos y Develando Arcanos, Universidad de Magallanes, Punta Arenas, pp. 151-161. 
Gómez Otero, J., and Novellino, P. (2011). Diet, nutritional status and oral health of hunter-gatherers from the central-northern coast of Patagonia and the Chubut River lower valley, Argentina. International Journal of Osteoarchaeology 21: 643-659.

Goñi, R. (2000). Arqueología de momentos históricos fuera de los centros de conquista y colonización: un análisis de caso en el sur de la Patagonia. In Desde el País de los Gigantes: Perspectivas Arqueológicas en Patagonia, Tomo 1, Universidad Nacional de la Patagonia Austral, Río Gallegos, pp. 283-296.

Greyling, T. (2006). Factors Affecting Possible Management Strategies for the Namib Feral Horses. Doctoral dissertation, North-West University, Potchefstroom.

Guenther, M. G. (1986). The Nharo Bushmen of Botswana: Tradition and Change, Helmut Buske Verlag, Hamburg.

Güldemann, T. (2008). A linguist's view: Khoe-Kwadi speakers as the earliest food-producers of southern Africa. Southern African Humanities 20: 93-132.

Hall, T. D. (1998). The Río de la Plata and the greater southwest: a view from world-system theory. In Guy, D. J., and Sheridan, T. E. (eds.), Contested Ground: Comparative Frontiers on the Northern and Southern Edges of the Spanish Empire, University of Arizona Press, Tucson, pp. 150-166.

Hämäläinen, P. (2003). The rise and fall of Plains Indian horse cultures. Journal of American History 90: 833862.

Hämäläinen, P. (2008). The Comanche Empire, Yale University Press, New Haven.

Harrison, R. (2003). "The magical virtue of these sharp things": colonialism, mimesis and knapped bottle glass artefacts in Australia. Journal of Material Culture 8: 311-336.

Harrison, R. (2004). Shared Landscapes: Archaeologies of Attachment and the Pastoral Industry in New South Wales, University of New South Wales Press, Sydney.

Heizer, R. F. (1941). The direct historical approach in California archaeology. American Antiquity 7: 98-122.

Henrichsen, D. (2013). Establishing a precolonial 'modern' cattle-and-gun society: (re-)pastoralisation, mercantile capitalism and power amongst Herero in nineteenth-century Central Namibia. In Bollig, M., Schnegg, M., and Wotzka, H.-P. (eds.), Pastoralism in Africa: Past, Present and Future, Berghahn, Oxford, pp. 201-229.

Hernández, J. V. (2002). Hondas y boleadoras en la América hispana. Anales del Museo de América 10: 113136.

Huffman, T. N. (2007). Handbook to the Iron Age: The Archaeology of Pre-Colonial Farming Communities in Southern Africa, University of KwaZulu-Natal Press, Scottsville.

Humphreys, A. J. B., and Thackeray, A. I. (1983). Ghaap and Gariep: Later Stone Age Studies in the Northern Cape, South African Archaeological Society, Claremont.

Hurst Thomas, D., Pendleton, L. S. A., and Cappanari, S. C. (1986). Western Shoshone. In d'Azevedo, W. L. (ed.), Handbook of North American Indians 11: Great Basin, Smithsonian Institution, Washington, DC, pp. 262-283.

Ingold, T. (1980). Hunters, Pastoralists and Ranchers: Reindeer Economies and Their Transformations, Cambridge University Press, Cambridge.

Ingold, T. (2000). The Perception of the Environment: Essays in Livelihood, Dwelling and Skill, Routledge, London.

Isenberg, A. C. (2000). The Destruction of the Bison, Cambridge University Press, Cambridge.

Jacobs, N. J. (2001). The great Bophuthatswana donkey massacre: discourse on the ass and the politics of grass and class. American Historical Review 106: 485-507.

Jones, K. L. (1999). Warfare, reorganization and readaptation at the margins of Spanish rule: the southern margin (1573-1882). In Salomon, F., and Schwartz, S. B. (eds.), The Cambridge History of the Native Peoples of the Americas, Volume 3, South America, Part 2, Cambridge University Press, Cambridge, pp. 138-187.

Kienetz, A. (1977). The key role of the Orlam migrations in the early Europeanization of South-West Africa (Namibia). International Journal of African Historical Studies 10: 553-572.

Kimber, R. G. (1988). Smallpox in Central Australia: evidence for epidemics and postulations about the impact. Australian Archaeology 27: 63-68.

Kinahan, J. (1996). The archaeology of social rank among eighteenth-century nomadic pastoralists in southern Namibia. African Archaeological Review 13: 225-245.

Kooyman, B., Hills, L. V., McNeil, P., and Tolman, S. (2006). Late Pleistocene horse hunting at the Wally's Beach site (DhPg-8), Canada. American Antiquity 71: 101-121.

Landals, A. (2004). Horse heaven: change in late precontact to contact period landscape use in southern Alberta. In Kooyman, B., and Kelley, J. H. (eds.), Archaeology on the Edge: New Perspectives from the Northern Plains, University of Calgary Press, Calgary, pp. 231-262.

Lau, B. (1986). Conflict and power in nineteenth-century Namibia. Journal of African History 27: 29-39. 
Layton, R. H. (1992). Australian Rock Art: A New Synthesis, Cambridge University Press, Cambridge.

Legassick, M. (1989). The northern frontier to c. 1840: the rise and decline of the Griqua people. In Elphick, R., and Gilliomee, H. (eds.), The Shaping of South African Society 1652-1680, Maskew Miller Longman, Cape Town, pp. 358-420.

Lema, V. S., della Negra, C., and Bernal, V. (2012). Explotación de recursos vegetales silvestres y domesticados en Neuquén: implicancias del hallazgo de restos de maíz y algarrobo en artefactos de molienda del holoceno tardío. Magallania 40: 229-247.

Levine, M. A. (1998). Eating horses: the evolutionary significance of hippophagy. Antiquity 72: 90-100.

Lourandos, H. (1997). Continent of Hunter-Gatherers: New Perspectives in Australian Prehistory, Cambridge University Press, Cambridge.

Mandrini, R. (1999). La economía indígena del ámbito pampeano-patagónico: ¿problema de las fuentes o ceguera de los historiadores? América Latina en la Historia Económica Boletín de Fuentes 12: 39-58.

Martinič, M. (1995). Los Aonikenk: Historia y Cultura, Ediciones de la Universidad de Magallanes, Punta Arenas.

Martinič, M., and Quiroz, D. (1989). El uso ecuestre entre los Aonikenk. Anales del Instituto de la Patagonia (Serie Ciencias Sociales) 19: 29-42.

McBryde, I. (1987). Goods from another country: exchange networks and the people of the Lake Eyre Basin. In Mulvaney, D. J., and White, J. P. (eds.), Australians to 1788, Fairfax Syme and Weldon Associates, Broadway, pp. 253-274.

McGranaghan, M. (2012). Foragers on the Frontiers: The /Xam Bushmen of the Northern Cape, South Africa, in the Nineteenth Century. Doctoral dissertation, University of Oxford, Oxford.

McKnight, T. L. (1969). The Camel in Australia, Melbourne University Press, Melbourne.

McShane, C., and Swart, S. (2011). Designing equids in South Africa and North America. Safundi: The Journal of South African and American Studies 12: 203-227.

Menard, C., Duncan, P., Fleurance, G., Georges, J.-Y., and Lila, M. (2002). Comparative foraging and nutrition of horses and cattle in European wetlands. Journal of Applied Ecology 39: 120-133.

Métraux, A. (1946). Indians of the Gran Chaco. In Steward, J. H. (ed.), The Handbook of South American Indians Volume 1 The Marginal Tribes, Smithsonian Institution, Washington DC, pp. 197-370.

Mincham, C. J. (2008). A Social and Cultural History of the New Zealand Horse. Doctoral dissertation, Massey University, Albany.

Mishkin, B. (1940). Rank and Warfare among the Plains Indians, American Ethnological Society, New York.

Mitchell, P. J. (2006). Remembering the Mountain Bushmen: observations of nineteenth century huntergatherers in Lesotho as recorded by Victor Ellenberger. Southern African Field Archaeology 15(16): 3-11.

Mitchell, P. J. (2015). Horse Nations: The Worldwide Impact of the Horse on Indigenous Societies Post-1492, Oxford University Press, Oxford.

Morales, M., Barberena, R., Belardi, J. B., Borrero, L., Cortegoso, V., Durán, V., Guerci, A., Goñi, R., Gil, A., Neme, G., Yacobaccio, H., and Zárate, M. (2009). Reviewing human-environment interactions in arid regions of southern South America during the past 3000 years. Palaeogeography, Palaeoclimatology, Palaeoecology 281: 285-295.

Moreno, E. J., and Videla, B. A. (2005). Rastreando ausencias: la hipótesis del abandono del uso de los recursos marinos en el momento ecuestre en la Patagonia continental. Magallania 36: 91-104.

Mulvaney, D. J. (1976). The "chain of connection": the material evidence. In Peterson, N. (ed.), Tribes and Boundaries in Australia, Australian Institute of Aboriginal Studies, Canberra.

Musters, G. C. (1871). At Home with the Patagonians, John Murray, London.

Nimmo, D. G., and Miller, K. K. (2007). Ecological and human dimensions of management of feral horses in Australia: a review. Wildlife Research 34: 408-417.

Nuevo Delaunay, A. (2012). Disarticulation of Aónikenk hunter-gatherer lifeways during the late-19th and early-20th centuries: two case studies from Argentinean Patagonia. Historical Archaeology 46: 149-166.

Nuevo Delaunay, A. (2013). Tecnología lítica y asentamientos modernos: análisis de un conjunto de bolas líticas del siglo XX. In Zangrando, A. F., and Barberena, R. (eds.), Tendencias Teórico-Metodológicas y Casos de Estudio en la Arqueología de la Patagonia, Museo de Historia Natural de San Rafael, San Rafael, pp. 469-474.

Orquera, L. A. (1987). Advances in the archaeology of the Pampas and Patagonia. Journal of World Prehistory 1: 333-413.

Orton, J. D. (2015). The introduction of pastoralism to southernmost Africa: thoughts on new contributions to an ongoing debate. Azania: Archaeological Research in Africa 50: 250-258.

Osaki, M. (1984). The social influence of change in hunting technique among the central Kalahari San. African Study Monographs 5: 49-62. 
Osborn, A. (1983). Ecological aspects of equestrian adaptations in aboriginal North America. American Anthropologist 85: 563-591.

Ouzman, S. (2005). The magical arts of the raider nation: central South Africa's Korana rock art. South African Archaeological Society Goodwin Series 9: 101-113.

Palermo, M. A. (1986). Reflexiones sobre el llamado “complejo ecuestre" en la Argentina. Runa 16: 157-178.

Palermo, M. A. (1988). La innovación agropecuaria entre los indígenas Pampeano-Patagónicos: génesis y procesos. Anuario del Instituto de Estudios Históricos y Sociales 3: 43-91.

Palermo, M. A. (1999). Mapuches, Pampas y mercados coloniales. Noticias de Antropología y Arqueología http://www.etnohistoria.com.ar/htm/21_articulo.htmAccessed September 2015.

Paterson, A. G. (2005a). Hunter-gatherer interactions with sheep and cattle pastoralists from the Australian arid zone. In Veth, P., Smith, M., and Hiscock, P. (eds.), Desert Peoples; Archaeological Perspectives, Blackwell, Oxford, pp. 261-275.

Paterson, A. G. (2005b). Early pastoral landscapes and culture contact in Central Australia. Historical Archaeology 39(3): 28-48.

Paterson, A. G. (2008). The Lost Legions: Culture Contact in Colonial Australia, AltaMira, Lanham, MD.

Paterson, A. G. (2012). Rock art as historical sources in colonial contexts. In Oland, M. H., Hart, S. M., and Frink, L. (eds.), Decolonizing Indigenous Histories: Exploring Prehistorical/Colonial Transitions in Archaeology, University of Arizona Press, Tucson, pp. 66-85.

Penn, N. (2005). The Forgotten Frontier: Colonist and Khoisan on the Cape's Northern Frontier in the Eighteenth Century, DoubleStorey, Cape Town.

Pero, A. (2002). The Tehuelche of Patagonia as chronicled by travelers and explorers in the nineteenth century. In Briones, C., and Lanata, J. L. (eds.), Archaeological and Anthropological Perspectives on the Native Peoples of Pampa, Patagonia and Tierra del Fuego, Bergin and Garvey, Westport, CT, pp. 103-119.

Peterson, N. (1976). The natural and cultural areas of Aboriginal Australia: a preliminary analysis of population groupings with adaptive significance. In Peterson, N. (ed.), Tribes and Boundaries in Australia, Australian Institute of Aboriginal Studies, Canberra, pp. 50-71.

Phillips, G. H. (1993). Indians and Intruders in Central California, 1769-1849. University of Oklahoma Press, Norman.

Picon, F. R. (1983). Pasteurs du Nouveau Monde: Adoption de l'Elévage chez les Guajiros, Editions de la Maison des Sciences de l'Homme, Paris.

Podestá, M. M., and Albornoz, A. (2007). El arte rupestre del sitio Paredón Lanfré dentro del contexto arqueológico del valle del río Manso inferior (Pcia. de Río Negro). In Tras las Huellas de la Materialidad, Actas del XVI Congreso Nacional de Arqueología Argentina, Facultad de Humanidades, Universidad Nacional de Jujuy, Jujuy, pp. 429-434.

Polo Acuña, J. (1999). Los Wayúu y los Cocina: dos caras differentes de una misma moneda en la resistencia indígena en la Guajira, siglo XVIII. Anuario Colombiano de Historia Social y de la Cultura 26: 7-29.

Ponomarenko, E., and Dyck, I. (2007). Ancient Nomads of the Eurasian and North American Grasslands, Canadian Museum of Civilization, Ottawa.

Prates, L. (2009). El uso de recursos por los cazadores-recolectores posthispánicos de Patagonia continental y su importancia arqueológica. Relaciones de la Sociedad Argentina de Antropología 34: 201-229.

Ramson, W. S. (1966). Australian English: An Historical Study of the Vocabulary, 1788-1898, Australian National University Press, Canberra.

Reynolds, H. (2006). The Other Side of the Frontier: Aboriginal Resistance to the European Invasion of Australia, University of New South Wales Press, Sydney.

Rinn, D. (1975). The Acquisition, Diffusion and Distribution of the European Horse among Blackfoot Tribes in Western Canada. Masters dissertation, University of Manitoba, Winnipeg.

Romero, F. G., and Spota, J. C. (2006). Algunos comentarios críticos acerca de 15 años de arqueología en los fortines pampeanos. Relaciones de la Sociedad Argentina de Antropología 31: 161-185.

Rosenfeld, A. (1982). Style and meaning in Laura art: a case study in the formal analysis of style in Palaeolithic art. Mankind 13: 199-217.

Sadoun, A., and Cabrera, M. C. (2008). A review of the nutritional content and technological parameters of indigenous sources of meat in South America. Meat Science 80: 570-581.

Saeger, J. (2000). The Chaco Mission Frontier: The Guaycuruan Experience, University of Arizona Press, Tucson.

Saignes, T. (1985). "La guerra selvaje" en los confines de los Andes y del Chaco: resistencia chiriguana a la colonización europea. Quinto Centenario 8: 103-123.

Salama, S. A. (1984). Role played by arthropods in transmission of African horsesickness. In Epidemiological and Immunological Studies on South African Horsesickness and Trials of Production of Inactivated Vaccine, PL-480, Final Technical Report, Cairo, pp. 44-48. 
Shimkin, D. N. (1986). The introduction of the horse. In d'Azevedo, W. L. (ed.), Handbook of North American Indians 11: Great Basin, Smithsonian Institution, Washington DC, pp. 517-524.

Slatta, R. W. (1990). Cowboys of the Americas, Yale University Press, New Haven.

Smith, A. B. (2005). African Herders: Emergence of African Pastoral Traditions, AltaMira, Walnut Creek, CA.

Smith, M. (2013). The Archaeology of Australia's Deserts. Cambridge University Press, Cambridge.

Smith, B. W., and van Schalkwyk, J. A. (2002). The white camel of the Makgabeng. Journal of African History 43: 235-254.

Speth, J. D. (1983). Bison Kills and Bone Counts: Decision-Making by Ancient Hunters, University of Chicago Press, Chicago.

Speth, J. D. (2010). The Paleoanthropology and Archaeology of Big-Game Hunting, Springer, New York.

Speth, J. D., and Spielmann, K. A. (1983). Energy source, protein metabolism, and hunter-gatherer subsistence strategies. Journal of Anthropological Archaeology 2: 1-31.

Spicer, E. H. (1962). Cycles of Conquest: The Impact of Spain, Mexico, and the United States on the Indians of the Southwest, 1533-1960, University of Arizona Press, Tucson.

Steele, J., and Politis, G. (2009). AMS ${ }^{14} \mathrm{C}$ dating of early human occupation of southern South America. Journal of Archaeological Science 36: 419-429.

Swart, S. (2010). Riding High: Horses and Human History in South Africa, Wits University Press, Johannesburg.

Sylvain, R. (2001). Bushmen, Boers and baasskap: patriarchy and paternalism on Afrikaner farms in the Omaheke region, Namibia. Journal of Southern African Studies 27: 717-737.

Tapson, A. J. (1962). Indian warfare on the Pampa during the colonial period. Hispanic American Historical Review 42: 1-28.

Tateo, A., DePalo, P., Ceci, E., and Centoducati, P. (2008). Physicochemical properties of meat of Italian heavy draft horses slaughtered at the age of eleven months. Journal of Animal Science 86: 1205-1214.

Traill, A. (1996). !Khwa-ka hhouiten hhouiten, "the rush of the storm': the linguistic death of /Xam. In Skotnes, P. (ed.), Miscast: Negotiating the Presence of the Bushmen, University of Cape Town Press, Cape Town, pp. 161-184.

Turner, D. H. (1973). The rock art of Bickerton Island. Oceania 43: 286-325.

van der Merwe, P. J. (1988). Die Noordwaartse Beweging van die Boere voor Die Groot Trek, The State Library, Pretoria.

van Sittert, S. J., Drew, T. M., Kotze, J. L., Strydom, T., Weyer, C. T., and Guthrie, A. J. (2013). Occurrence of African horse sickness in a domestic dog without apparent ingestion of horse meat. Journal of the South African Veterinary Association 84: 948.

Velásquez, H., Méndez, C., Reyes, O., Trejo, V., Sanhueza, L., Quiroz, D., and Jackson, D. (2007). Campamentos residenciales tardíos a cielo abierto en el alto río Cisnes (region de Aisén): Appeleg 1 (CIS 009). Magallania 35: 121-132.

Vinnicombe, P. V. (1976). People of the Eland, University of Natal Press, Pietermaritzburg.

Wallace, M. (2011). A History of Namibia, Hurst, London.

Wilson, A., Mellor, P. S., Szmaragd, C., and Mertens, P. P. C. (2009). Adaptive strategies of African horse sickness virus to facilitate vector transmission. Veterinary Research 40: 16.

Zalba, S. M., and Cozzani, N. C. (2004). The impact of feral horses on grassland bird communities in Argentina. Animal Conservation 7: 35-44.

Zappia, N. A. (2008). The Interior World: Trading and Raiding in Native California, 1700 1863, Doctoral dissertation, University of California, Santa Cruz. 